\title{
Romance Histórico Moderno e a História Cultural: Pontos de articulação na obra Memorial do convento, de José Saramago
}

\author{
Modern Historical Novel and Cultural History: Points of \\ articulation in Memorial do convento, by José Saramago
}

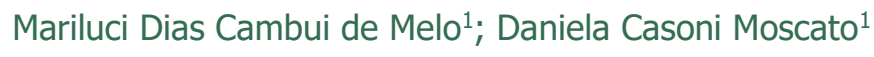

\section{RESUMO}

Este artigo tem o propósito de explicitar, a partir da análise do livro Memorial do convento, de José Saramago, as relações existentes entre a Literatura e a História. Nesse sentido, buscou-se perceber de que maneira as mudanças ocorridas na pesquisa historiográfica, principalmente as suscitadas pelo movimento da História Cultural, atingiram a produção e a análise literária. Assim, o presente trabalho procura elencar as características do romance histórico moderno, gênero que apresenta elementos da criação literária e da pesquisa histórica, e demonstrar como a obra aqui analisada se encaixa nesse conceito. Além disso, a partir do estudo da linguagem da obra em questão (o uso do humor, da ironia, da metalinguagem e o papel do narrador), este artigo procurou evidenciar o intuito do autor em fazer uma reflexão crítica sobre acontecimentos da história portuguesa. Esta pesquisa buscou fundamentos em autores como Roger Chartier (2002), Paul Veyne (1998), Hayden White (1991), Georg Lukács (2011), entre outros.

Palavras-chave: História. Literatura. História Cultural. Romance Histórico Moderno.

\begin{abstract}
This article has the purpose of explaining, from the analysis of the book Memorial do convento, by José Saramago, the existing relations between Literature and History. In this sense, it was sought to understand how the changes occurred in the historiographic research, especially those raised by the Cultural History movement, reached the production and the literary analysis. Thus, the present work seeks to list the characteristics of the modern historical novel, a genre that presents elements of literary creation and historical research, and demonstrate how the work analyzed here fits into this concept. In addition, from the study of the language of the work in question (the use of humor, irony, metalanguage and the role of the narrator), this article sought to highlight the author 's intention to make a critical reflection on events in Portuguese history. This research sought foundations in such authors as Roger Chartier (2002), Paul Veyne (1998), Hayden White (1991), Georg Lukács (2011), among others.
\end{abstract}

Keywords: History. Literature. Cultural History. Modern Historical Novel.

\footnotetext{
${ }^{1}$ UEPG - Universidade Estadual de Ponta Grossa, Ponta Grossa/PR - Brasil.
} 


\section{INTRODUÇÃO}

A História busca estudar, reconstruir e relatar os acontecimentos que envolvem a vida dos homens e das sociedades. Não diferente disso, a Literatura também busca recriar a vivência humana e as relações sociais.

Considerando os entrecruzamentos entre os diversos campos do conhecimento, podemos encontrar pontos de articulação entre as disciplinas de Literatura e de História e também perceber como o discurso, o uso de determinada linguagem, interfere na transmissão e no entendimento da mensagem.

Assim, é possível perceber que um evento histórico não é entendido apenas como o que aconteceu, mas se reveste de nuances diversas, dependendo da maneira como ele é "contado". Dessa forma é que História e Literatura

[...] se juntam e se conciliam para produzir interpretações, questionamentos, revisões e resgate dos personagens e fatos históricos, propiciando discussões e debates; enfim, reavaliando o passado à luz de novas possibilidades narrativas (BOTOSO, 2010, p. 38).

Nesse sentido, tanto o ofício do historiador quanto o do escritor é uma busca pelo que já não é mais, mas poderia ser, oferecendo aos seus leitores "versões e variações sobre aspectos de uma dada realidade" (BOTOSO, 2010, p. 39), utilizando a linguagem como instrumento para construir/reconstruir fatos, acontecimentos e personagens históricos.

É nesse sentido que este trabalho busca em Memorial do convento reconhecer os entrelaçamentos entre História e Literatura, estudando as relações entre o discurso literário e o histórico, considerando que tais discursos não são neutros, mas refletem interesses e motivações pessoais e provocam efeitos sociais (SOARES, s/d, p. 5).

Desse modo, seguiremos as orientações de Roger Chartier (2002) sobre a análise do livro enquanto fonte histórica. Também serão consideradas as observações de Hayden White (1991), Paul Veyne (1998), Georg Lukács (2011), Sandra Pesavento (2004), Edgar de Decca e Ria Lamaire (2000) a respeito das mudanças ocorridas no campo da historiografia e dos entrelaçamentos das disciplinas de História e Literatura. O trabalho de Maristela Silveira (2008), em virtude de sua especificidade e estreita ligação com o objeto de pesquisa deste trabalho, servirá de base para a análise da linguagem e das personagens da obra.

Visando constatar a influência da moderna historiografia sobre a literatura contemporânea, o artigo apresentará as características do romance histórico moderno usando o livro Memorial do convento como parâmetro, mostrando como José Saramago se utiliza dos recursos linguísticos para lançar um olhar crítico sobre fatos da história portuguesa.

A escolha dessa obra, escrita em 1982, se justifica por três fatores: o tema, a forma e o autor. A respeito do tema, o livro traz um enredo que envolve eventos e personagens históricos, discorrendo sua trama a partir da ordem do rei $D$. João $V$ de se construir um grande convento na cidade portuguesa de Mafra. 
Em se tratando da forma, isto é, da maneira como o texto foi organizado, percebemos a intenção do autor de sujeitar os conhecimentos históricos a questionamentos e revisões a partir de um olhar crítico para o passado.

Finalmente, considerando a biografia do autor e os valores por ele cultivados (expressos em discursos, declarações, entrevistas, etc.), pode-se perceber em Memorial do convento a preocupação em mostrar as desigualdades sociais, a luta do povo pela sobrevivência e o papel das pessoas anônimas na construção da História.

Assim, esta pesquisa busca, primeiramente, estabelecer a estreita ligação entre História e Literatura a partir do conceito de "romance histórico". Na sequência o artigo propõe a análise da obra em questão, relacionando aspectos linguísticos e históricos do livro. Por último, traça-se um paralelo entre as mudanças historiográficas propostas pela História Cultural e as mudanças ocorridas no campo da literatura contemporânea.

\section{HISTÓRIA E LITERATURA: APROXIMAÇÕES}

Sendo este trabalho uma breve análise de como uma obra literária apresenta personagens e eventos históricos, é preciso que se faça uma reflexão sobre como essas duas disciplinas, Literatura e História, se relacionam entre si. O texto literário, em especial aquele que apresenta características da vivência de um grupo social em determinada época, se coloca na confluência entre o campo da Arte e o campo da Ciência, visto que ele é tanto produto cultural quanto objeto de pesquisa (MORAIS e DIAS, 2013).

A historiadora Sandra Pesavento (2004) considera que História e Literatura podem ser vistas como "diferentes formas de dizer o mundo, que guardam distintas aproximações com o real" (p. 80). Se essas duas disciplinas são "diferentes formas de dizer", então "ambas necessitam de um autor que Ihes interprete e lhes dê sentido." (BOTOSO, 2010, p. 38).

Dessa forma o papel do historiador e do escritor, enquanto autores desses modos de dizer, é de suma importância, pois a escolha que fazem do discurso utilizado para materializar suas obras revela suas intenções e ideologias.

Sendo assim, História e Literatura se articulam em uma relação estreita, já que buscam a representação da vida e dos fatos relacionados ao Homem e ao Mundo. Portanto essas duas disciplinas, com suas características e especificidades, podem contribuir para o conhecimento, promovendo um novo olhar sobre os fatos históricos e seus sujeitos.

Por isso o próprio texto se torna fonte de pesquisa histórica na medida em que o uso da linguagem revela muito sobre a visão do mundo e do homem que o pesquisador/escritor deseja transmitir. 0 uso da linguagem por parte do historiador e do escritor é a forma de expressão de suas ideias.

Assim, pode-se dizer que tanto a História quanto a Literatura buscam

[...] estimular comportamentos e formas de pensamento desejados, propondo modelos e pondo em ação estratégias discursivas tais como a persuasão, a sedução, a verossimilhança, a credibilidade e a autoridade das palavras (DECCA e LEMAIRE, 2000, p. 10, grifo nosso). 
O que se conclui, então, é que a forma discursiva é tão importante quanto o conteúdo narrativo, seja na pesquisa histórica (que precisa de um texto que veicule seus resultados e análises), seja na criação literária.

Para o historiador francês Roger Chartier (2002), o texto precisa ser compreendido e analisado sob dois conjuntos de dispositivos: um que reúne as estratégias linguísticas e as intenções do autor, e outro que diz respeito às estratégias de edição e veiculação do texto escrito (p. 71).

O estudo proposto aqui irá se deter nos aspectos do primeiro conjunto, ou seja, analisar o lugar social do autor (sua posição social e ideológica) e os elementos linguísticos presentes no texto. Essas duas dimensões devem propiciar o diálogo entre a realidade social do autor e os recursos semânticos e estilísticos por ele usados na obra.

Eduardo Navarrete (2011), ao estudar as ideias de Chartier, considera que para este pesquisador o livro, enquanto fonte de pesquisa histórica, deve ser estudado a partir de uma metodologia específica, em que se leve em consideração não apenas o teor do que está escrito, mas o contexto de produção da obra.

Portanto, a análise de um texto literário deve observar a ideologia do autor que transparece em sua obra, o papel do leitor na recepção (leitura) do livro, as negociações sociais que são necessárias na composição da obra para que o autor alcance seus objetivos diante do leitor, o suporte (meio de veiculação) em que cada obra literária é inscrita, etc.

O que Chartier denomina de negociações sociais está intimamente ligado ao seu conceito de representação. Para ele, a representação é o instrumento pelo qual se revela um objeto ausente através de uma imagem (CHARTIER, 2002, p. 74). No caso específico do texto literário, a "imagem" é a palavra, que traz à mente do leitor o objeto (ou conceito) proposto.

No entanto, mesmo que autor e leitor utilizem do mesmo código (signo linguístico), o significado, dependendo da vivência de cada leitor, pode variar. Então, com relação às negociações sociais, o que se pretende é perceber como ocorre a construção de significações mediante o texto, quer dizer, como se percorre o caminho entre o que o autor pretende dizer e o que o leitor de fato compreende (NAVARRETE, 2011). Tal caminho é permeado pela realidade sócio-histórica de cada um, pelos seus valores, crenças, ideologias políticas e religiosas, habilidades linguísticas e cognitivas, etc.

Na análise de uma obra literária há, então, a necessidade de compreender o uso que o autor faz de determinados termos ou construções sintáticas visto que essas escolhas não são aleatórias. E essas escolhas produzem efeitos de sentido, ou seja, abrem possibilidade para múltiplas interpretações (NAVARRETE, 2011).

Assim, ao analisar uma obra literária pelo viés histórico é importante considerar qual a intencionalidade do texto, qual o efeito que o autor deseja produzir na mente de seu(s) leitor(es), quais os recursos que o autor utiliza para produzir tais efeitos de sentido.

Pode-se dizer, então, que tanto o historiador quanto o escritor pesam, na composição de suas obras, o valor de cada palavra. E não somente na elaboração dos textos, mas, no caso do historiador, na análise histórica e literária de fontes escritas. Então tanto a pesquisa histórica quanto a arte literária se articulam em torno da linguagem, como será visto a seguir. 


\subsection{A linguagem como ponto de articulação entre História e Literatura}

O debate acerca da ciência histórica (sua epistemologia, metodologia e objeto de estudo) é por demais amplo para ser abordado neste trabalho. Muitos são os que se dedicam ao tema, por diferentes e controversos caminhos que ora se aproximam e ora se afastam. Para cumprir os objetivos desta pesquisa, nos atemos a nomes como Paul Veyne (1998) e Hayden White (199), cujas obras, olhando a História sob seu modo de apresentação linguístico/narrativo (MORAIS e DIAS, 2013), aproximam a prática do historiador com a prática do romancista.

Para Veyne, historiador e arqueólogo francês, a História, por não possuir método, não limitar seu campo de estudo e não explicar e prever os fatos não pode ser considerada uma ciência. Nas palavras desse historiador, "a história não é uma ciência e não tem muito a esperar das ciências; ela não explica e não tem método [...] os historiadores narram fatos reais que têm o homem como ator; a história é um romance real' (VEYNE, 1998, p. 6, grifo nosso).

Veyne ainda considera que não há possibilidade de voltar ao passado e reviver os acontecimentos; tudo que se tem dos eventos passados são vestígios (relatos, objetos, construções, etc.), e é com esse material que o historiador elabora sua pesquisa (VEYNE, 1998). A pesquisa histórica, transformada em texto é, portanto, uma descrição do passado, não o passado em si mesmo. Veyne considera o historiador como um escritor e a ciência histórica como a narrativa dos fatos; essa narrativa, que se dá a partir das escolhas do historiador (subjetividade), "aproximaria a história assim escrita da história romanceada" (VEYNE, 1998, p. 8).

Hayden White (1991) também corrobora a ideia acima apresentada, pois afirma que o fato histórico não existe per si, isto é, o passado não existe mais e nem os fatos passados tornam a acontecer. Portanto a História nada mais é do que a forma narrativa como os historiadores descrevem esses fatos. Esse autor considera "o discurso histórico primordialmente como interpretação, mais do que como uma explicação ou descrição" (WHITE, 1991, p. 6).

Sendo assim, para esses historiadores, a História pode ser entendida como uma criação literária, na qual os historiadores se valem do texto (discurso) para relatar o que aconteceu. Dessa forma, a análise de uma obra literária como fonte histórica precisa levar em conta a estética literária, os recursos linguísticos e semânticos, as influências literárias, a diversidade de gêneros literários e sua caracterização, etc.

Como visto, historiadores como Veyne e White aproximam o ofício do historiador ao ofício do escritor, porém conserva-se uma diferenciação entre os dois, já que o historiador narra o acontecido, enquanto o escritor tem a liberdade da ficção.

Mas e quando a ficção literária se baseia no acontecido? Quando o escritor adentra o campo historiográfico e se apropria da pesquisa histórica para a elaboração de sua obra? Nesse caso, temos a conjunção da pesquisa histórica com a arte literária e surge outro gênero narrativo: o romance histórico.

\subsection{O romance histórico}

Os estudos sobre as confluências entre História e Literatura vêm se acentuando desde meados do século XX (FERREIRA, 1996, p. 24), principalmente com relação ao gênero literário denominado romance histórico. 
O romance histórico se caracteriza por atrelar ficção a bases históricas, ou seja, é um gênero que se propõe a "retratar e recuperar personagens que fizeram parte da história. Procura realçar e destacar o indivíduo, os seus sentimentos contraditórios, as suas falhas, a sua humanidade" (BOTOSO, 2010, p. 40).

Nesse sentido, o romance histórico desloca para a ficção literária fatos e personagens históricos; através da pesquisa histórica o escritor deseja criar o "efeito de realidade", ou seja, busca assemelhar a ficção a uma realidade que existiu ou poderia ter existido, revestindo a representação ficcional com o manto do real (BORGES, 2010, p. 99)

Antonio Roberto Esteves (1998), baseado nas obras de Georg Lukács, considera que as origens do romance histórico remontam ao escritor escocês Sir Walter Scott (1771-1832), cujas obras foram responsáveis por fixar os elementos que caracterizam o modelo de romance histórico. 0 esquema de Scott obedecia a dois princípios básicos:

1- A ação do romance ocorre num passado anterior ao presente do escritor, tendo como pano de fundo um ambiente histórico rigorosamente reconstruído, onde figuras históricas reais ajudam a fixar a época, agindo conforme a mentalidade de seu tempo.

2- Sobre esse pano de fundo histórico situa-se a trama fictícia, com personagens e fatos criados pelo autor. Tais fatos e personagens não existiram na realidade, mas poderiam ter existido, já que sua criação deve obedecer a mais estrita regra de verossimilhança (ESTEVES, 1998, p. 129).

Observa-se então que o romance histórico se caracteriza por apresentar a ação narrativa situada no passado (histórico) longínquo e por buscar reconstruir ambientes, costumes e valores da época histórica retratada, entremeando discurso historiográfico e discurso literário (BOTOSO, 2010, p. 40).

O filósofo húngaro Georg Lukács, em seus estudos sobre as relações entre História e Literatura, considera o romance histórico não apenas a partir de seu conteúdo, mas também pela sua forma, isto é, pela maneira como foi construído.

Assim é que, para Lukács (2011), o romance histórico é capaz de ressaltar as tensões entre as classes e os jogos de poderes que permeiam as relações sociais, sendo capaz de relacionar passado e presente. Com isso se quer dizer que o romance histórico propicia um olhar diferente para as relações humanas na História. Como observa Pedro Santos (2011), o enredo dos romances históricos deve interessar "menos como mito ou história e mais pela inerente carga de conflitos sociais ou morais que possam significar" (SANTOS, 2011, p. 290)

Portanto, o romance histórico precisa ser compreendido a partir do entendimento de que o autor possui e transmite em sua obra uma "consciência histórica" (SANTOS, 2011, p. 284), e essa consciência histórica transparece na carga psicológica que os personagens carregam e nas reflexões que apresentam sobre a sociedade retratada na obra.

Como será visto na próxima subseção, a própria estrutura da escrita (narrativa), tanto histórica quanto literária, passa por significativas transformações motivadas por uma nova forma de ver, pensar e contar a História. 


\subsection{0 novo romance histórico}

As alterações ocorridas na historiografia ao longo do tempo também acarretaram mudanças no formato do romance histórico. Surge, então, o "novo romance histórico" (ou "romance histórico moderno"), o qual se utiliza de recursos literários (intertextualidade, paródia, sátira, a metaficção, etc.) a fim de criar um discurso narrativo que apresente fatos históricos a partir de uma visão crítica (BOTOSO, 2010, p. 41-42).

Como afirma Rejane Ribeiro (2009), os romances históricos modernos evidenciam o papel do excêntrico, daquilo que está fora do centro das atenções, mas que habita as margens da História. Ribeiro (2009) considera ainda que o romance histórico moderno "não pretende contar a verdade, mas sim apresentar outras possibilidades de interpretação e tentar desvendar de quem é essa verdade" (RIBEIRO, 2009, p. 79).

Assim é que um dos aspectos característicos do romance histórico da pós-modernidade é o fato de haver nele múltiplas vozes e múltiplos pontos de vista, os quais propiciam um diálogo mais profundo entre o texto e o leitor (WEINHARDT, 2002). Em Memorial do convento tal característica salta aos olhos, uma vez que o narrador, em muitos momentos, expõe suas próprias reflexões sobre as circunstâncias narradas. O exemplo abaixo ajuda a ilustrar essa afirmação:

Já o padre Bartolomeu Lourenço regressou de Coimbra, já é doutor em cânones, confirmado de Gusmão por apelativo onomástico e firma escrita, e nós, quem somos nós para nos atrevermos a taxá-lo do pecado de orgulho, maior bem nos fará à alma perdoar-Ihe a falta de humildade em nome das razões que deu, assim possam sernos perdoados os nossos próprios pecados, esse e outros, que ainda o pior de tudo não será mudar de nome, mas de cara, ou de palavra. (SARAMAGO, 2007, p. 154).

Vemos aqui o narrador não apenas descrevendo o que aconteceu (o retorno do padre Bartolomeu de seus estudos em Coimbra), mas fazendo uma longa reflexão sobre o orgulho, os pecados da alma e a inconstância do homem, que não mantém sua palavra.

Outra característica do romance histórico moderno, conforme a professora e crítica literária Linda Hutcheon (apud WEINHARDT, 2002), é a chamada "autoconsciência do processo de constituição", que demonstra que personagens e/ou narrador têm consciência de seu ofício, ou seja, dentro da obra eles sabem que estão construindo a obra (daí o uso da "metalinguagem", conceito que será trabalhado posteriormente). Exemplos disso são os trechos a seguir:

[...] são comparações inventadas por quem escreve para quem andou na guerra, não as inventou Baltasar... (SARAMAGO, 2007, p. 106)

[...] isto se devendo ler com muita atenção para que não escape ao entendimento. (SARAMAGO, 2007, p. 265).

Observa-se que o narrador sabe que está escrevendo uma história e faz uma advertência àquele que a lerá. Não somente isso, mas ele também interfere diretamente na narrativa ao "inventar" suas comparações, dar sua opinião, antecipar acontecimentos dentro da linha temporal da narrativa, comentar as consequências dos atos das personagens, etc.

Para além da recriação do ambiente e dos fatos históricos, o romance histórico moderno visa, entre outros objetivos, reinterpretar, comentar e criticar a história. Na próxima seção, apresenta-se a 
análise de Memorial do convento sob a perspectiva do romance histórico moderno, observando as críticas e reflexões que o texto traz acerca da História.

\section{MEMORIAL DO CONVENTO: UM NOVO OLHAR PARA O PASSADO}

Um dos objetivos deste trabalho é analisar o livro Memorial do convento considerando-o como uma obra do gênero romance histórico moderno e observando como, por ele, é possível tecer reflexões acerca do passado. Para tanto, nas seções anteriores vimos como a ligação entre História e Literatura se estreita no romance histórico e como as mudanças na historiografia também acarretaram novos rumos na estrutura da narrativa histórica.

A partir dessas bases preliminares podemos, então, estudar mais detidamente o livro de José Saramago. A obra tem como pano de fundo a construção do convento na cidade de Mafra, em Portugal, no século XVIII, um grandioso monumento mandado construir pelo rei D. João $V$ em razão de uma promessa feita a Deus para que a rainha engravidasse e lhe desse um herdeiro.

Muitos eventos históricos são narrados na obra: o casamento dos reis, a construção do convento, os ataques dos holandeses à costa do Brasil, as tentativas do padre Bartolomeu Lourenço de construir uma "máquina de voar", etc. Por outro lado, entrelaçando esses fatos, há uma narrativa ficcional, com personagens e enredo criados pela imaginação do escritor português: é a história de amor entre Baltasar Sete-Sóis e Blimunda Sete-Luas, pessoas comuns do povo; e o voo da "passarola", a máquina idealizada pelo padre Bartolomeu Lourenço.

No romance em questão, narra-se a construção de duas grandes obras, ambas ordenadas pelo rei $D$. João V: o convento de Mafra e a passarola. A nobreza e o clero, como classes dominantes, se orgulham e se promovem com essas obras; porém a efetiva construção delas se dá pelo povo comum, que trabalha, perde sua liberdade, seus bens e suas vidas para que o nome de $\mathrm{D}$. João $\mathrm{V}$ brilhe na história oficial.

Ancorado nos estudos do historiador francês Jacques Le Goff, Valdeci Borges (2010) afirma que a análise histórica de um documento precisa levar em consideração quais as circunstâncias (históricas, políticas e sociais) em que esse documento foi produzido, seguindo o pressuposto de que é necessário conhecer o autor do documento e perceber quais eram suas intenções ao produzi-lo.

José Saramago nasceu na província portuguesa de Ribatejo em 16 de novembro de 1922, em uma família de agricultores pobres; em 1924 sua família transfere-se para Lisboa. Por questões de ordem financeira, Saramago não pôde frequentar a universidade, tendo trabalhado como serralheiro, funcionário público e jornalista antes de poder dedicar-se exclusivamente à carreira literária (SARAIVA, s/d, p. 2)

Saramago foi membro do Partido Comunista Português e um dos fundadores da Frente Nacional para a Defesa da Cultura. Em 1995 recebeu o Prêmio Camões (1995), o mais importante prêmio literário da língua portuguesa; em 1998 foi agraciado com o Prêmio Nobel de Literatura. José Saramago faleceu na ilha espanhola de Lanzarote a 18 de junho de 2010 (SARAIVA, s/d, p.2). 
No site oficial da Fundação Saramago ${ }^{2}$, encontramos textos do autor que nos auxiliam a compreender quais seus princípios e valores. Entre esses textos, há uma autobiografia, na qual ele ressalta a influência de seus avós maternos na constituição de seu caráter, destacando que eram camponeses pobres e analfabetos.

No discurso proferido por ele por ocasião do recebimento do Prêmio Nobel de Literatura em 1998, Saramago recorda-se de seus avós e dos moradores de sua aldeia natal, e enfatiza que eram

[...] gente popular que conheci, enganada por uma Igreja tão cúmplice como beneficiária do poder do Estado e dos terra-tenentes latifundistas, gente permanentemente vigiada pela polícia, gente, quantas e quantas vezes, vítima inocente das arbitrariedades de uma justiça falsa (SARAMAGO, 1998).

Ainda em outro discurso diante de Academia Sueca em 1998, Saramago faz uma contundente defesa dos Direitos Humanos ${ }^{3}$, denunciando que "as injustiças multiplicam-se no mundo, as desigualdades agravam-se, a ignorância cresce, a miséria alastra" (SARAMAGO, 1998).

Em entrevista concedida na Universidade Federal de Minas Gerais, Saramago se confessa um historiador frustrado e alega que aquilo que escreve "decorre do gosto pela história, pela leitura dos clássicos, pela língua e do apego às [suas] raízes populares" (DUARTE, MILARD e MIRANDA, 1986, p. 94). É nesse viés que se pode afirmar que José Saramago apresenta um "compromisso com a vida do povo e com os problemas sociais do povo" (SANTOS, 2011, p. 298).

Não só nos discursos e entrevistas, mas também em muitos dos seus romances, José Saramago deixa transparecer suas posições políticas, suas raízes rurais e sua crítica à Igreja Católica. Seu posicionamento ideológico faz com que seus textos se revistam sempre de uma crítica à sociedade e às injustiças sociais, fazendo de seus personagens porta-vozes dos menos favorecidos.

José Saramago, referindo-se especificamente a Memorial do convento, diz que o livro não se trata de um "exercício gratuito de imaginação", mas tem o propósito de "corrigir a história" (DUARTE, MILARD e MIRANDA, 1986). É nesse sentido que se pode afirmar que Memorial do convento, por se tratar de um romance histórico moderno, apresenta questionamentos e críticas sobre a História, "problematizando o conhecimento, favorecendo o surgimento de reflexões sobre questões dadas como certas" (MELO e COSTA, 2017, p. 20), como veremos nas próximas páginas.

\subsection{Características do novo romance histórico na obra de José Saramago}

Como já citado anteriormente, o filósofo Georg Lukács analisa as relações entre a História e a Literatura, tecendo reflexões acerca do romance histórico, tanto sob o ponto de vista da temática (conteúdo) quanto sob a técnica (forma) escolhida pelos romancistas para criar suas obras (2011).

Lukács, em seus estudos, afirma que romance histórico deve retratar "o passado como a pré-história do presente" (2011, p. 17), ou seja, ele não é "inteiramente passado" (2011, p. 21), mas deve guardar relações com o tempo presente. Sendo o romance histórico um gênero que se originou do romance

\footnotetext{
2 A Fundação José Saramago foi fundada em 2007 com o propósito de, segundo sua Declaração de Princípios, promover ações em favor dos Direitos Humanos e da preservação do meio ambiente. Disponível em: https://www.josesaramago.org. Acesso em 15/03/2018.

3 Declaração Universal dos Direitos Humanos, assinada em Nova Iorque no dia 10 de Dezembro de 1948.
} 
social do século XVIII (LUKÁCS, 2011), ele deve apresentar uma identificação com os problemas e lutas do povo (SANTOS, 2011). Lucas André Kölln (2012), ao analisar o trabalho de Lukács, afirma que

[...] é objeto de sua [de Lukács] pesquisa, portanto, a maneira como se relaciona o senso de historicidade de uma época (que começa, como indica o pioneirismo de Scott, no século XVIII) e a maneira como a obra está estruturada, desde suas manifestações formais quanto temáticas, sua abordagem acerca dos personagens, as questões com as quais dialoga e a imagem que constrói acerca da sociedade e seus conflitos em relação ao passado, presente e, por consequência, futuro. (KÖLLN, 2012, p. 2)

Lukács não apenas olhou para os temas ou conteúdos dos romances históricos, mas observou e analisou sua forma, a construção do discurso literário, os caminhos escolhidos pelos autores na elaboração de suas obras. Para ele, perceber como o texto foi feito nos leva a compreender como o autor deseja que ele seja entendido.

Dessa forma veremos algumas características da linguagem empregada por José Saramago em Memorial do convento, buscando perceber através da linguagem a "consciência histórica" do autor.

\subsubsection{A linguagem do texto e o papel do narrador}

José Saramago é um autor que subverte as normas da pontuação em suas obras. No romance aqui analisado ele utiliza longos parágrafos e longas sentenças, quase não utilizando ponto final, sendo a vírgula o sinal de pontuação mais utilizado. Também não utiliza o travessão ou as aspas para destacar as falas das personagens, apenas adicionando-as ao longo do texto.

Assim ele força o leitor a se deter mais demoradamente no texto a fim de descobrir onde começam e onde terminam os diálogos das personagens, fazendo necessárias repetidas leituras do mesmo trecho. Ao mesmo tempo em que isso pode tornar a leitura mais lenta também dá ao leitor a chance de apreender com mais cuidado o sentido daquilo que o autor deseja dizer.

Essa forma de mesclar as falas das personagens na narração do texto também apresenta outra característica da obra, que é o uso do discurso indireto livre ${ }^{4}$, ou seja, a mistura de vozes dentro da narrativa. A voz do narrador e a voz das personagens misturam-se a ponto de não se perceber onde termina o discurso de um e começa o discurso de outro. O trecho abaixo ilustra essa afirmação:

Disse o padre Bartolomeu Lourenço a Sete-Sóis, Falei com os desembargadores destas matérias, disseram-me que iam ponderar o teu caso, se vale a pena fazeres petição, depois me darão uma resposta, E quando será isso, padre, quis Baltasar saber, ingênua curiosidade de quem acaba de chegar à corte e lhe ignora os usos, Não te sei dizer, mas tardando, talvez eu possa dizer uma palavra a sua majestade, que me distingue com a sua estima e proteção, Pode falar com el-rei, espantou-se Baltasar, e acrescentou, Pode falar a el-rei e conhecia a mãe de Blimunda, que foi condenada pela Inquisição, que padre é este padre, palavras estas últimas que Sete-Sóis não terá dito em voz alta, só inquieto as pensou (SARAMAGO, 2007, p. 58-59).

\footnotetext{
4 "É um registro de fala ou de pensamento de personagem, que consiste num meio-termo entre o discurso direto e o indireto, porque apresenta expressões típicas do personagem mas também a mediação do narrador." (GANCHO, 2004, p. 39).
} 
Pode-se, então, observar neste trecho a ausência de pontos finais, travessões, aspas ou sinais de interrogação ou exclamação. As falas das personagens são introduzidas apenas pelo uso da letra maiúscula, ainda que no meio da frase.

Além disso, é possível perceber que o narrador tem o conhecimento até mesmo dos pensamentos e dos sonhos das personagens (narrador onisciente), pois ele informa o que Baltasar pensou. Em outro trecho encontramos exemplo dessa afirmação:

São meandros do inconsciente real, como aqueles outros sonhos que sempre D. Maria Ana tem, vá lá explicá-los, quando el-rei vem a seu quarto, que é ver-se atravessando o Terreiro do Paço para os lados do açougue [...] enquanto o infante D. Francisco, seu cunhado [...] dança em redor dela [...] (SARAMAGO, 2007, p. 17).

Também D. João V sonhará esta noite. Verá erguer-se do seu sexo uma árvore de Jessé, frondosa e toda povoada dos ascendentes de Cristo [...] (SARAMAGO, 2007, p. 18).

Percebe-se a sutil crítica que o narrador faz ao mencionar que, após o intercurso sexual, o rei sonha com seu descendente que também seja da descendência do bíblico rei Davi; enquanto isso, a rainha sonha com seu jovem cunhado.

O narrador também não se limita apenas a contar o que se passa no presente da narrativa, mas antecipa ao leitor o futuro das personagens:

[...] e com esta sábia e céptica sentença se concluiu a conversação em palácio, primeira das muitas com que $D$. Francisco fatigará a rainha, em Belém onde ela agora está, em Belas para onde irá com demora, em Lisboa quando enfim for regente (SARAMAGO, 2007, p. 112, grifo nosso).

Em outro trecho, ao comentar sobre as medidas da pedra usada na construção da varanda do convento, o narrador transita entre o passado (tempo da narrativa) e o nosso tempo presente:

Faça as contas quem quiser, que a laje tem de comprimento trinta e cinco palmos, de largura quinze, e a espessura é de quatro palmos [...] e quando um dia se acabarem palmos e pés por se terem achado metros na terra, irão outros homens a tirar outras medidas e encontrarão sete metros, três metros, sessenta e quatro centímetros [...] (SARAMAGO, 2007, p. 236).

Também se percebe que, em muitas ocasiões, o narrador explicita sua opinião a respeito de determinado assunto. Exemplo disso, ainda nas primeiras páginas do romance, quando D. João vai ao quarto de sua esposa D. Maria Ana e estão presentes muitos nobres e há todo um ritual a cumprir: "está o quarto uma assembleia, as majestades fazem mútuas vênias, nunca mais acaba o cerimonial" (SARAMAGO, 2007, p. 15, grifo nosso).

Vemos que o narrador conhece todos os detalhes da trama, está em todos os lugares, insere observações, faz críticas e reflexões sobre a vida, os atos e os pensamentos das personagens, às vezes emitindo juízos de valor sobre alguns temas. E é através da "voz" do narrador (anônimo na obra) que podemos discernir as intenções e ideologia do autor (José Saramago). 


\subsubsection{Carnavalização: a inversão dos papéis dos personagens}

Mikhail Bakhtin desenvolve a teoria da carnavalização da literatura, observando que "a linguagem simbólica do carnaval, festa popular onde os indivíduos se fantasiam e trocam seus papéis sociais, se transporta para a literatura" (MELO e COSTA, 2017, p. 18)

Em outras palavras, assim como no carnaval os indivíduos podem assumir papéis sociais diversos (o empregado pode ser o patrão, o plebeu pode ser o nobre, o homem pode ser mulher etc.), na literatura as personagens podem inverter seus papéis sociais. Claudiana Soerensen (2011) define que a carnavalização é o princípio da "inversão, onde os marginalizados apropriam-se do centro simbólico, numa espécie de explosão de alteridade, onde se privilegia o marginal, o periférico, o excludente" ( $p$. 320).

Em Memorial do convento acontece essa inversão da ordem social: Saramago desloca a figura do rei e da rainha de Portugal para a margem da narrativa e centraliza seu enredo no casal Baltasar e Blimunda, personagens que representam o povo.

Para observar como a carnavalização acontece em Memorial do convento, e retomando alguns pontos já evidenciados por Melo e Costa (2017), vamos analisar os personagens principais da obra: o rei D. João V, a rainha D. Maria Ana Josefa, o padre Bartolomeu de Lourenço, Baltasar e Blimunda. Os três primeiros são personagens importantes da história de Portugal; os dois últimos são personagens criados pela imaginação do autor e que representam o povo.

D. João V, que reinou em Portugal entre 1706 e 1750, ficou conhecido na História como um grande construtor e empreendedor de obras monumentais (como o convento de Mafra, descrito na obra); também pela renovação do esplendor da corte portuguesa durante o seu reinado, caracterizado pelo luxo e ostentação (SILVEIRA, 2008, p. 37).

Para Silveira, o rei D. João V esbanjava o dinheiro, advindo da cobrança de altos impostos e da exploração de matéria-prima das colônias portuguesas, em obras que não beneficiavam o povo (SILVEIRA, 2008). E é assim que Saramago retrata esse rei, evidenciando sua futilidade e vaidade.

No trecho abaixo o narrador nos mostra que o rei medita sobre o que vai fazer com tantas riquezas, mas, em nenhum momento, o monarca pensa em realizar obras para o bem-estar do povo. Sua preocupação é em agradar o clero para, depois, receber benefícios deste na mesma medida:

Medita D. João V no que fará a tão grandes somas de dinheiro [...] e sempre conclui que a alma há-de ser a primeira consideração, por todos os meios devemos preservála, sobretudo quando a podem consolar também os confortos da terra e do corpo (SARAMAGO, 2007, p. 219).

O romance apresenta um rei que não se preocupa em cuidar de seu povo ou do seu reino. O narrador destaca que aquele que tem o dever de governar não o está fazendo quando salienta que o reino "anda mal governado, que nele está de menos a justiça, e não reparam que ela está como deve estar, com sua venda nos olhos, sua balança, sua espada [...]" (SARAMAGO, 2007, p. 182).

Ao lado do rei temos a rainha D. Maria Ana Josefa (1683-1754), retratada como uma mulher submissa, cuja única função é fornecer herdeiros ao rei, porém a infertilidade da rainha coloca sua posição em risco. Para D. Maria Ana Josefa, ser rainha é um peso e uma prisão; em alguns momentos de reflexão 
ela deixa transparecer as angústias de seu papel de rainha e expressa o desejo de ser uma mulher "normal", comum: "farta estou eu de ser rainha e não posso ser outra coisa" (SARAMAGO, 2007, p. 112).

O romance apresenta ainda a figura do padre Bartolomeu Lourenço de Gusmão. Conforme os registros, Bartolomeu de Gusmão (1685-1724) era um clérigo erudito (SILVEIRA, 2008), que se dedicou a construir a "passarola", um engenho mecânico que pudesse voar. Em 1709 ele conseguiu seu intento e fez voar diante da corte portuguesa um balão de ar quente, o que lhe valeu o apelido de "Padre Voador".

Bartolomeu de Gusmão, sendo padre, não pensa ou se comporta como padre e até mesmo confessa: "dirão que me converti ao judaísmo, e é verdade, dirão que me entrego a feitiçarias, e também verdade é" (SARAMAGO, 2007, p. 185). Ele, por suas ideias que destoavam das leis da Igreja Católica, tanto no campo da ciência quanto em questões de fé, acabou sendo acusado pela inquisição de heresia. Fugiu para a Espanha, onde faleceu na cidade de Toledo.

Analisando o personagem do padre Bartolomeu, é possível perceber como seu papel social se inverte ao longo do enredo. Ele faz parte de uma instituição, que persegue aos que têm ideias contrárias a ela, e acaba perseguido por essa mesma instituição.

Ao lado desse núcleo temático centrado na corte portuguesa (nobreza e clero), há outro núcleo centrado na vida comum do povo comum e representado por Baltasar e Blimunda. Baltasar Mateus, cujo apelido de família é Sete-Sóis, é um ex-soldado que perde uma das mãos em combate e, tendo recebido baixa do exército, procura meios de sobrevivência em Lisboa.

Blimunda de Jesus é uma jovem cuja mãe foi condenada, pela Inquisição, ao degredo, sob acusações de bruxaria e heresia. Ela também possui dons de visão dos quais o padre Bartolomeu deseja se aproveitar para construir sua máquina de voar.

Baltasar e Blimunda se conhecem durante um auto de fé (evento público de condenação ou penitência realizado pelo Tribunal do Santo Ofício) em Lisboa e se unem como casal por vontade própria. Diferentemente do que acontece com o casal real, cujo casamento é apenas o cumprimento de um contrato social, há entre eles um sentimento de cuidado e de cumplicidade.

Até as relações conjugais demonstram consentimento e respeito mútuos, como diz o narrador: "[...] este casal, ilegítimo por sua própria vontade, não sacramentado na igreja, cuida pouco de regras e respeitos, e se a ele apeteceu, a ela apetecerá, e se ela quis, quererá ele" (SARAMAGO, 2007, p. 73).

Baltasar e Blimunda são mostrados como pessoas livres em seu modo de pensar e agir. Eles não se definem pelas regras sociais ou religiosas, mas estabelecem, eles mesmos, suas próprias regras em seu relacionamento.

Fica claro, então, a representação carnavalesca dos personagens: se o rei é mostrado como um homem frívolo e alienado, Baltasar é retratado como honesto, trabalhador e corajoso; se a rainha é descrita como uma mulher submissa, Blimunda se mostra como mulher senhora de si e de suas ações. 


\subsubsection{Metalinguagem}

Outra característica bastante presente na obra de José Saramago é o recurso da metalinguagem, que pode ser compreendido como o uso da linguagem para falar de si mesma. De acordo como Débora Silva (s/d), "a metalinguagem é usada quando se deseja falar da própria linguagem usada na comunicação, ou seja, quando a preocupação do emissor está voltada para o próprio código ou linguagem" (SILVA, s/d).

No contexto da obra que aqui é analisada, percebemos o uso da metalinguagem nas interferências que o narrador faz para explicar ou mencionar que está escrevendo um livro. Temos, então, um narrador que se preocupa em alertar o leitor sobre o que este vai ler.

Segundo Marilda Beijo (2012), encontramos no texto de José Saramago

[...] aquele tipo de escrita consciente do oficio do escritor e do ato de escrever e que deixa transparecer na própria escrita, metalinguisticamente, essa consciência, pelo fato de colocar em foco a construção da criação literária (BEIJO, 2012, p. 48).

Os trechos abaixo podem ilustrar melhor o conceito de metalinguagem na obra estudada:

[...] tendo constantemente motivos para ajoelhar-se, ora a cruz, ora o patriarca, ora el-rei, ora os frades, ora os cónegos, já nem se levantava, bem poderemos escrever que estava muito povo de joelhos (SARAMAGO, 2007, p. 132, grifo nosso).

[...] já que não podemos falar-lhes das vidas, por tantas serem, ao menos deixemos os nomes escritos, é essa a nossa obrigação, só para isso escrevemos, torná-los imortais [...] (SARAMAGO, 2007, p. 233, grifo nosso).

Fica evidente que o narrador tem consciência de seu ofício de escritor da história e de que sua narrativa está permeada de invenções, interpretações, omissões, lacunas. Nesse sentido, o próprio narrador é o primeiro crítico da sua obra, revelando falhas e possíveis equívocos, convidando o leitor a exercer uma leitura mais crítica e reflexiva sobre a obra que tem nas mãos.

Em se tratando de uma obra que reúne ficção e história, é oportuno salientar que o narrador convida o leitor a refletir que parte da escrita é "inventada" por ele próprio e que toda escrita tem uma intenção por detrás.

Desse modo o uso da metalinguagem corrobora os conceitos de White (1991), já discutidos anteriormente, para quem o discurso histórico não é uma descrição dos fatos, mas uma interpretação destes. Ao chamar a atenção para o ato de escrever, o romance histórico evidencia que o texto é apenas uma das visões possíveis a respeito dos fatos.

\section{A HISTÓRIA CULTURAL, SEUS DESDOBRAMENTOS E OS NOVOS OBJETOS DE PESQUISA HISTÓRICA}

Como já mencionado anteriormente, o século XX trouxe novos rumos no campo da pesquisa historiográfica. Uma das mudanças mais significativas foi o interesse dos historiadores pela cultura popular e pelo dia-a-dia do povo comum, já iniciado a partir do final do século XIX, com a História Cultural, e aprofundado no movimento da Nova História Cultural a partir da década de 1970. 
Na História Cultural, o interesse dos historiadores se voltava para as grandes obras-primas artísticas, literárias e filosóficas, entendendo que essas manifestações culturais eram representativas de toda uma sociedade. Aos poucos, porém, o foco dos pesquisadores foi se deslocando das grandes manifestações políticas, sociais e artísticas para os pequenos fragmentos do cotidiano, daí surgindo o movimento da Nova História Cultural.

Esse movimento defendia que a História não podia ser resumida aos grandes acontecimentos ou aos atos dos grandes personagens históricos, mas que ela acontecia nos detalhes da vida corriqueira, no cotidiano das pessoas comuns, em suas tradições e costumes, nos objetos do dia-a-dia, nas manifestações populares de arte e cultura, etc.

Assim há uma mudança no campo das fontes e objetos de estudos, que passaram das grandes obrasprimas da arte para os elementos cotidianos da vida das classes operárias, artesãs e campesinas. Nesse contexto a influência das ideias marxistas na segunda metade do século XX também se fizeram sentir na produção de alguns historiadores, entre os quais destaca-se Edward Palmer Thompson e os adeptos da Nova Esquerda Inglesa (New Left).

O movimento da Nova Esquerda Inglesa, influenciado pelo materialismo dialético de Karl Marx, defendia a análise das questões sociais a partir da estrutura de classes sociais e das lutas de classe (LOPES, 2010). Por materialismo dialético podemos, grosso modo, entender a ação do homem na construção das relações sociais e a possibilidade de intervenção humana no processo histórico (LOPES, 2010).

Sob essa perspectiva, a História é vista sob o ponto de vista de outros atores sociais, que não somente os grandes vultos históricos: homens e mulheres comuns, soldados, servos, artesãos, operários, crianças, etc., passam a ter suas histórias contadas. Na obra Memorial do convento, apesar de figurar importantes nomes da história portuguesa, os protagonistas são um homem e uma mulher comuns: Baltasar e Blimunda.

É através do olhar de Baltasar que a história da construção do grande convento de Mafra, em Portugal, é contada. É ele quem representa o camponês, o soldado, o trabalhador, as pessoas que, apesar de não terem seus nomes gravados na História, trabalharam na sua construção.

Baltasar é o "porta-voz" de camponeses e artesãos que são obrigados a trabalhar sob precárias condições. Em um dos episódios narrados no livro, quando D. João $V$ deseja que se apressem a construção do convento, o engenheiro-chefe da obra adverte que não há como terminar a obra em curto prazo. A isso, o rei ordena aos corregedores do reino que

[ı, reúnam e enviem para Mafra quantos operários se encontrarem nas suas jurisdições, sejam eles carpinteiros, pedreiros ou braçais, retirando-os, ainda que por violência, dos seus mesteres, e que sob nenhum pretexto os deixem ficar [...] porque ninguém está acima da vontade real (SARAMAGO, 2007, p. 282, grifo nosso).

Ainda demonstrando que "ninguém está acima da vontade do rei", D. João V enfatiza: "assim o quero, ordeno e determino" (SARAMAGO, 2007, p. 281). Em outro trecho o narrador considera sobre as relações de poder entre o governo (rei) e o povo: "e os homens, que nunca viram o rei, os homens que o rei nunca viu, os homens, mesmo não o querendo vêm, entre soldados e quadrilheiros [...]" (SARAMAGO, 2007, p. 285). 
Essa é uma das muitas referências do livro à violência que se comete contra os homens livres que, sem direito de escolha, são recrutados à força para o trabalho no convento. Ainda mais direta é a crítica que se faz a essa arbitrária ordem real quando o narrador pondera:

Quanto pode um rei. Está sentado em seu trono [...] e daí, daqui ou dacolá [...], despacha ordens para que [...] venham os homens válidos, ou nem tanto, a trabalhar neste meu convento de Mafra [...] (SARAMAGO, 2007, p. 284-285, grifo nosso).

Considerando o que já foi dito acerca das posições ideológicas de José Saramago, fica clara a intenção do autor em questionar o poder de um governante que, "sentado em seu trono", pode determinar sobre a vida de homens e mulheres a seu bel-prazer, apenas para satisfazer sua vaidade.

No trecho transcrito acima, o autor faz uma transição proposital das pessoas do discurso, ou seja, passa-se da voz do narrador ("está [o rei] sentado em seu trono") para a voz do rei ("neste meu convento"). Isso evidencia que, apesar de ter sido a multidão anônima de homens tirados à força de suas casas, de suas famílias e de seus ofícios que construíram essa monumental obra, o convento "pertence" ao rei.

\section{CONSIDERAÇÕES FINAIS}

Como visto, História e Literatura apresentam relações muito estreitas, principalmente no romance histórico, gênero híbrido que articula a pesquisa histórica e as técnicas literárias.

O romance histórico, sob a influência das mudanças na historiografia, também sofreu desdobramentos. O movimento da História Cultural alterou o modo de ver a História e fazer a pesquisa histórica, e essas alterações se fizeram sentir no campo da Literatura com o surgimento do novo romance histórico.

A análise do livro Memorial do convento demonstrou como essa obra apresenta características do novo romance histórico e como as escolhas linguísticas de José Saramago deixam entrever que, mais do que narrar eventos da história portuguesa, o livro faz uma análise crítica a respeito da sociedade e de suas desigualdades.

O uso da linguagem irônica, a inversão dos papeis sociais, as interferências do narrador durante a narrativa apresentam personagens e situações que retratam tensões sociais e a situação precária das classes menos favorecidas pela sobrevivência; por outro lado, as elites (nobreza e clero) são mostradas como opressoras e exploradoras.

Percebe-se assim que, no entrelaçamento das técnicas literárias e historiográficas, o discurso histórico ganha novos contornos e a História passa a ser percebida sob um novo olhar. É justamente esse novo olhar que Saramago busca em sua obra. Ele mesmo declarou, em entrevista, que a História que é ensinada "dá-nos apenas um percurso, quando são possíveis mil outros [...] É essa a minha atitude em relação ao passado. Ver o que há mais além daquilo que já está dito [...]" (DUARTE, MILARD e MIRANDA, 1986, p. 95)

O próprio Saramago, ao refletir sobre o enredo de um de seus romances, observa que um revisor de História "cansado de ver como a dita História cada vez é menos capaz de surpreender, decide pôr no lugar de um 'sim' um 'não', subvertendo a autoridade das 'verdades históricas'"' (SARAMAGO, 1998). 
E são justamente essas "verdades históricas", cristalizadas nos documentos oficiais e nos livros escolares, que são questionadas na obra que aqui nos propusemos a analisar. Aspectos valorizados pela História Cultural, e pelos movimentos historiográficos posteriores, podem ser encontrados nessa obra, tais como: a valorização da mulher (no papel de Blimunda), a denúncia da opressão sofrida pelas classes menos favorecidas, a luta do povo pobre pela sobrevivência, a influência da Igreja e da religião na sociedade, a corrupção da nobreza e do clero, etc.

Dessa forma a análise de Memorial do convento evidencia que esta obra se encaixa no conceito de romance histórico moderno, sendo fruto da pesquisa histórica e da arte da criação literária de José Saramago, e veículo de propagação de sua ideologia fortemente voltada para as questões sociais.

\section{REFERÊNCIAS}

BEIJO, Marilda. O viés ensaístico na ficção de José Saramago. 2012. 160 f. Doutorado em Letras. Instituição de Ensino: Universidade Estadual Paulista Júlio de Mesquita Filho - Assis/SP. Biblioteca Depositária: FCL- UNESP/ASSIS Disponível em: http://capesdw.capes.gov.br/capes. Acesso em 21 jul. 2018.

BORGES, Valdeci R. História e Literatura: algumas considerações. Revista de Teoria da História, Universidade Federal de Goiás, 2010.

BOTOSO, Altamir. Romance histórico e pós modernidade. Revista de Letras da Universidade Católica de Brasília, v.3, n.1-2, 2010.

BUENO, Aparecida de Fátima. Três momentos do romance histórico de José Saramago. Boletim do CESP - v. 19, n. 24 - jan./jun. 1999.

BURKE, Peter. A grande tradição. In: BURKE, Peter. 0 que é história cultural? Rio de Janeiro: Zahar, 2004.

CHARTIER, Roger. 0 mundo como representação. In: CHARTIER, Roger. À beira da falésia. Editora da Universidade Federal do Rio Grande do Sul, 2002.

DECCA, Edgar Salvadori de; LAMAIRE, Ria. Org. Pelas margens: outros caminhos da história e da literatura. Campinas, Porto Alegre: Ed. da Unicamp. Ed. da Universidade - UFRGS, 2000.

DUARTE, Lélia Parreira; MALARD, Letícia; MIRANDA, Wander Melo. José Saramago, tecedor da história. Revista do Centro de Estudos Portugueses, p. 90-100, dez. 1986. Disponível em: http://www.periodicos.letras.ufmg.br/index.php/cesp/article/view/4447/4222. Acesso em: 15 mar. 2018.

ESTEVES, A. R. O novo romance histórico brasileiro. In: ANTUNES, L. Z. (Org.). Estudos de Literatura e Linguística. Assis: UNESP, 1998.

FERREIRA, Antonio Celso. História e Literatura: fronteiras móveis e desafios disciplinares. POSHISTÓRIA, UNESP/Assis-SP, v 4, p. 23-44, 1996.

Fundação Saramago. Disponível em: https: //www.josesaramago.org. Acesso em 15/03/2018

GANCHO, Cândida Vilares. Como analisar narrativas. 7 ed. São Paulo: Editora Ática, 2004. 
KÖLLN, Lucas André B. O Romance Histórico. Revista Tempos Históricos. Volume 16 - $1^{0}$ Semestre - 2012 - p. 179 - 184. Resenha

LOPES, Itamar C. e outros. Teoria da História IV. Ponta Grossa: UEPG/NUTEAD, 2010.

LUKÁCS, Georg. O Romance Histórico. Tradução de Rubens Enderle. São Paulo: Boitempo, 2011. 440 p.

MELO, Mariluci D. C.; e COSTA, Lourenço R. da. História e Literatura: Romance Histórico, Desconstrução e Carnavalização na obra Memorial do Convento, de José Saramago. Revista Ateliê de História, v.5. n. 1. Ponta Grossa: UEPG, 2017. Disponível em: http://www.revistas2.uepg.br/index.php/ahu/article/view/9897. Acesso em 01/03/2018.

MORAIS, Julierme.; e DIAS, Rodrigo F. Reflexões em torno do "ofício do historiador" e sua legitimidade epistemológica: o que Veyne, White, Certeau, Gay e Chartier têm a nos dizer? Revista Aedos, Universidade Federal do Rio Grande do Sul, n. 12 vol. 5 - jan/jul 2013.

NAVARRETE, Eduardo. Roger Chartier e a Literatura. Revista Tempo, Espaço e Linguagem (TEL), UEPG/UNICENTRO, v. 2 no 3 p.23-56 set./dez. 2011.

PESAVENTO, Sandra. História \& História Cultural. Belo Horizonte: Autêntica, 2004.

RIBEIRO, Rejane de Almeida. Aspectos dos romances históricos tradicional e pós-moderno. Scientia FAER, Olímpia - SP, Ano 1, Volume 1, 2009.

SANTOS, Pedro Brum. Literatura e intervenção: romance histórico no Brasil. Revista Floema, Universidade Estadual do Sudoeste da Bahia, ano VII, n. 9, p. 283-303, jan./jun. 2011.

SARAIVA, João G. N. José Saramago segundo a micro-história: algumas reflexões sobre o romance Memorial do convento (1982). Disponível em: http://docplayer.com.br/14051583-Josesaramago-segundo-a-micro-historia-algumas-reflexoes-sobre-o-romance-memorial-do-convento1982.html. Acesso em 02/02/2018.

SARAMAGO, José. Discurso pronunciado na Academia Sueca, por ocasião da premiação do Nobel de Literatura. 1998. Disponível em: https://www.josesaramago.org/nobel/. Acesso em: $16 / 03 / 2018$.

Memorial do convento. 32 ed. Rio de Janeiro: Bertrand Brasil, 2007.

SILVA, Débora. Metalinguagem. Sem data. Disponível em: https://www.estudopratico.com.br/metalinguagem/. Acesso em 31/01/2018.

SILVEIRA, Maristela S. Literatura e História no Memorial do Convento: uma apresentação irônica das personagens. Dissertação de mestrado. Universidade Regional Integrada, Frederico Westphalen, 2008.

SOARES, Valter. História e Literatura: é possível sambar? Sem data. Universidade Estadual Feira de Santana, BA. Disponível em: http://www.uesb.br/anpuhba/artigos/anpuh_II/valter_guimaraes_soares.pdf. Acesso em 05/06/2016.

SOERENSEN, Claudiana. A carnavalização e o riso segundo Mikhail Bakhtin. Revista Travessias. v. 5, no 1. Cascavel: UNIOESTE, 2011. 
VEYNE, Paul M. Como se escreve a história; Foucault revoluciona a história. Trad. de Alda Baltar e Maria Auxiadora Kneipp. 4a ed. - Brasília: Editora Universidade de Brasília, 1998. 285 p.

WEINHARDT, Marilene. Considerações sobre o romance histórico. Revista Letras. Curitiba, n.43, p. 11-23, 1994. Editora da UFPR, 2002.

WHITE, Hayden. Teoria literária e escrita da história. Revista Estudos Históricos, CPDOC/FGV, Rio de Janeiro, vol. 7, n. 13, 1991, p. 21-48.

Submissão: 29/05/2018

Aceito: $23 / 08 / 2018$ 